\title{
Penyuluhan Kesehatan Tentang Seks Bebas Pada Remaja SMPN 4 Sigi
}

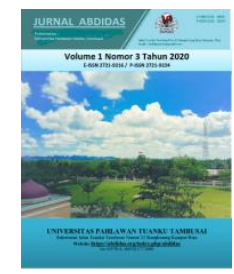

\section{Freny R Mbaloto ${ }^{1}$, Diah Fitri Purwaningsih ${ }^{2}$,Mutmainnah HS $^{3}$}

STIK Indonesia Jaya, Indonesia ${ }^{1,2,3}$

E-mail: $\underline{\text { frenymbaloto@gmail.com }}{ }^{1} \underline{\text { diah vitri85@yahoo.co.id }{ }^{2} \text { mutmainnah.flo@gmail.com }{ }^{3}}$

\begin{abstract}
Abstrak
Setiap tahun di Amerika Serikat, lebih dari 400.000 anak dilahirkan oleh ibu remaja yang beresiko tinggi mengalami kelahiran prematur, berat badan lahir rendah, dan meninggal saat melahirkan. Selain itu, kehamilan di usia remaja berdampak terhadap rendahnya pendidikan karena putus sekolah, masalah kesehatan mental dengan risiko tinggi harga diri yang rendah dan gejala depresi. Hasil SDKI 2017, dari remaja yang telah melakukan hubungan seksual pra nikah (59\%) wanita dan (74\%) pria melaporkan pertama kali melakukan hubungan seksual pada usia 15-19 tahun. Alasan melakukan hubungan seksual pertama kali dari 54\% wanita dan 46\% pria adalah saling mencintai, penasaran ingin tahu, terjadi begitu saja, dan terpengaruh teman. Pergaulan yang salah akan berdampak terhadap perilaku seks bebas. Peran orang tua sangat penting untuk mencegah hal tersebut tidak terjadi. Tetapi kenyataan yang banyak ditemukan bahwa karena kesibukan orang tua anak merasa kurang diperhatikan, terbatasnya waktu dalam memberikan pengawasan sehingga banyak anak remaja yang terjerumus dalam pergaulan bebas. Selain itu, pengaruh lingkungan (teman sebaya) dapat memberikan dampak negatif. Berdasarkan hal tersebut maka telah dilaksanakan pengabdian kepada masyarakat dengan sasaran remaja di SMPN 4 Sigi tentang seks bebas. Melalui pengabdian kepada masyarakat diharapkan remaja di SMPN 4 Sigi dapat mengetahui dan memahami mengenai seks bebas meliputi pengertian, penyebab, bahaya dan pencegahannya.
\end{abstract}

Kata kunci: remaja, seks bebas, penyuluhan kesehatan

\section{Abstract}

Each year in the United States, more than 400,000 children are born to adolescents mothers who are at high risk of premature birth, low birth weight, and death in childbirth. In addition, pregnancy in adolescence has an impact on low education due to school dropouts, mental health problems with a high risk of low self-esteem and symptoms of depression. The results of the 2017 IDHS show that adolescents who have had premarital sexual intercourse (59\%) of women and (74\%) of men reported their first sexual intercourse at the age of 15-19 years. The reasons for having sexual intercourse for the first time among 54\% of women and 46\% of men were loving each other, curious, just happened, and influenced by friends. The wrong relationship will have an impact on free sex behavior. The role of parents is very important to prevent this from happening. But the fact that many people find is that because of the busyness of the parents of children who feel they are not being cared for, they have limited time to provide supervision so that many teenagers fall into promiscuity. In addition, environmental influences (peers) can have a negative impact. Based on this, community service with the target of adolescents at SMPN 4 Sigi about Free Sex has been carried out. Through community service, it is expected that teenagers at Sigi Middle School can know and understand Free Sex including understanding, causes, dangers and prevention.

Keywords: adolescents, free sex, health promotion

Copyright (c) 2020 Freny R Mbaloto, Diah Fitri Purwaningsih, Mutmainnah HS

$\triangle$ Corresponding author

Address : JL. Towua, No.114, Palu-Sulteng

Email : frenymbaloto@gmail.com

Phone : :085398220091

DOI: https://doi.org/10.31004/abdidas.v1i4.51
ISSN 2721- 9224 (Media Cetak)

ISSN 2721- 9216 (Media Online) 


\section{PENDAHULUAN}

Remaja merupakan tahapan penting dalam kesehatan reproduksi. Pada masa remaja merupakan periode pematangan organ reproduksi manusia yang disebut juga dengan masa transisi yaitu terjadi perubahan fisik yang cepat, terkadang tidak seimbang dengan perubahan kejiwaaan dan mental. Ketidakseimbangan perkembangan mental pada masa transisi tersebut dapat menimbulkan kebingungan remaja yang dikhawatirkan membawa remaja pada perilaku seksual yang tidak bertanggungjawab seperti perilaku pacaran yang mengarah untuk melakukan hubungan seksual pranikah atau seks bebas (Levine, 2011).

Umur pertama kali berhubungan seksual erat hubungannya dengan status kesehatan reproduksi seseorang. Pada masa remaja organ reproduksi masih dalam tahap pertumbuhan sehingga belum berkembang secara sempurna. Hal tersebut menjadikannya rentan mengalami luka ketika berhubungan seksual. Selain itu hubungan seksual pada umur dini juga meningkatkan risiko masalah mental emosional, kognitif, perilaku, masalah kesehatan reproduksi lainnya, kehamilan remaja, serta dapat berdampak negatif bagi pendidikan dan konsekuensi sosial lainnya (Allison et al., 2008).

Kehamilan remaja erat dikaitkan dengan kehamilan tidak diinginkan (KTD), seringkali KTD diakhiri dengan usaha menggugurkan kandungannya untuk menghindari rasa malu dan sanksi masyarakat. Kehamilan pada remaja (umur 10-19) berisiko terhadap komplikasi kehamilan dan persalinan seperti eklampsi dan puerperal endometritis yang merupakan salah satu penyebab kematian maternal di dunia (Widdice et al., 2006).
Remaja melakukan semua itu karena mereka tidak mendapatkan pendidikan kesehatan reproduksi, sehingga kurang tahu bahaya atau dampak dari seks bebas. Remaja yang pada umumnya mempunyai rasa ingin tahu yang besar tentang 5 seksualitas terpaksa mencari informasi sendiri guna memuaskan rasa keingintahuannya tersebut (Strasburger \& Hogan, 2013). Pergaulan bebas di kalangan remaja yang akhir-akhir ini terjadi adalah karena remaja mencari pengetahuan dan informasi tentang seksualitas sendiri lewat teman yang sama-sama belum tahu akibat seks bebas, majalah-majalah porno, video, dan tempat hiburan malam yang memberikan akses informasi tanpa sensor sehingga proses kematangan alat reproduksi pada remaja tidak diimbangi dengan informasi yang baik (Guse et al., 2012).

Setiap tahun di Amerika Serikat, lebih dari 400.000 anak dilahirkan oleh ibu remaja yang beresiko tinggi mengalami kelahiran prematur, berat badan lahir rendah, dan meninggal saat melahirkan. Selain itu, kehamilan di usia remaja berdampak terhadap rendahnya pendidikan karena putus sekolah, masalah kesehatan mental dengan resiko tinggi harga diri yang rendah dan gejala depresi. Hasil SDKI 2017, dari remaja yang telah melakukan hubungan seksual pra nikah (59\%) wanita dan (74\%) pria melaporkan pertama kali melakukan hubungan seksual pada usia 15-19 tahun. Alasan melakukan hubungan seksual pertama kali dari 54\% wanita dan $46 \%$ pria adalah saling mencintai, penasaran ingin tahu, terjadi begitu saja, dan terpengaruh teman (BKKBN, 2017).

Masa remaja adalah masa pembelajaran. Meskipun remaja mendapatkan kesempatan 
mengembangkan potensi diri namun tetap memerlukan bekal, bimbingan dan pengarahan orang tua, pendidik serta dukungan lingkungan yang kondusif. Membekali mereka dengan pemahaman sebuah konsep hidup yang benar dalam proses pencarian jati diri. Dengan bimbingan, membentuk remaja merasa percaya diri karena secara kemampuan mereka belum teruji dalam menghadapi tantangan hidup. Keterlibatan orang tua, pendidik dan lingkungannya dalam memberikan pengarahan akan membentuk kesiapan mentalnya karena secara kejiwaan remaja masih labil, mudah kebinggungan ketika mengalami kesulitan dan kegagalan menjalani hidupnya (Sugiyanto, 2019).

Sejalan dengan penelitian yang dilakukan oleh Diana et al., (2020) bahwa ada pengaruh penyuluhan tentang bahaya seks bebas terhadap pengetahuan remaja di SMA Negeri 14 Bandar Lampung Tahun 2019, selanjutnya pengabdian kepada masyarakat yang dilaksanakan oleh Keswara \& Wardiyah (2017), menunjukan pemberian penyuluhan dapat memberikan peningkatan pengetahuan khususnya yang berkaitan dengan bahaya seks bebas bagi kesehatan reproduksi remaja.

SMPN 4 Sigi adalah salah satu Sekolah Menengah Pertama yang ada di Kabupaten Sigi, Propinsi Sulawesi Tengah. Berdasarkan hasil wawancara dengan wakil kepala sekolah bagian Humas saat survei kelompok sasaran, di SMPN 4 Sigi tidak ada kasus siswa/siswa putus sekolah disebabkan oleh karena pergaulan bebas/seks bebas. Selanjutnya, belum pernah juga dilakukan penyuluhan kesehatan dari Dinas maupun kampus kesehatan. Oleh karena Sigi adalah salah satu kabupaten dalam kategori $3 \mathrm{~T}$ dan sesuai visi misi STIK Indonesia Jaya, berdasarkan pertimbangan tersebut maka Tim menentukan sasaran pengabdian masyarakat di SMPN 4 Sigi.

\section{METODE}

Kegiatan pengabdian masyarakat dilaksanakan pada hari Jum'at, tanggal 2 Agustus 2019 di SMPN 4 Sigi. Sasaran adalah remaja seluruh siswa-siswi SMPN 4 Sigi. Metode pelaksanaan pengabdian masyarakat ini dilaksanakan melalui beberapa tahapan, yaitu yaitu mencari informasi terkait fenomena atau permasalahan pada remaja, menentukan alternatif pemecahan masalah, survei kelompok sasaran, identifikasi kebutuhan kegiatan, pelaksanaan dan evaluasi. Kegiatan dilaksanakan selama 1 hari dan di ikuti oleh 138 siswa-siswi SMPN 4 Sigi.

\section{HASIL DAN PEMBAHASAN}

Sebelum pelaksanaan kegiatan pengabdian kepada masyarakat, dilakukan beberapa persiapan. Pertama, tim mengidentifikasi berbagai sumber informasi dan referensi terkait pemasalahan pada remaja. Selanjutnya, menentukan alternatif pemecahan masalah yaitu melaksanakan penyuluhan kesehatan tentang seks bebas. Langkah ketiga, melakukan survei lokasi sesuai dengan sasaran. Tim mempersiapkan surat pemberitahuan pelaksanaan penyuluhan kesehatan. Kemudian langkah ke empat mengidentifikasi dan mempersiapkan kebutuhan pelaksanaan kegiatan meliputi: spanduk, SAP, leafleat, absensi, konsumsi, doorprice.

Kegiatan pengabdian kepada masyarakat 
dilaksanakan 1 hari pada hari Jum'at, 2 Agustus 2019 di SMPN 4 Sigi, Kabupaten Sigi, Propinsi Sulawesi Tengah. Tim (Dosen keperawatan STIK Indonesia Jaya) berjumlah 3 orang bersama mahasiswa PSIK semester V sejumlah 32 orang.

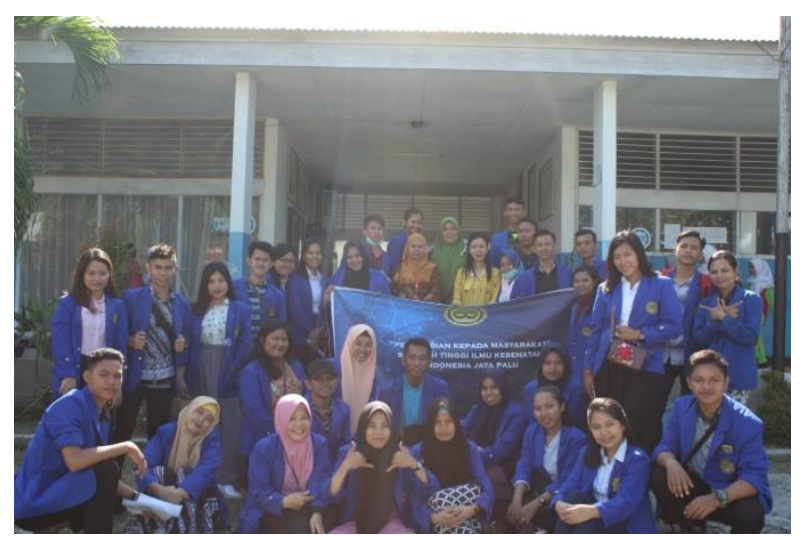

Gambar 1. Foto bersama Tim dan mahasiswa di Lokasi Pengabdian Masyarakat

Pengabdian masyarakat dalam bentuk penyuluhan kesehatan dikuti oleh seluruh siswasiswa SMPN 4 Sigi yang berjumlah 128 orang.
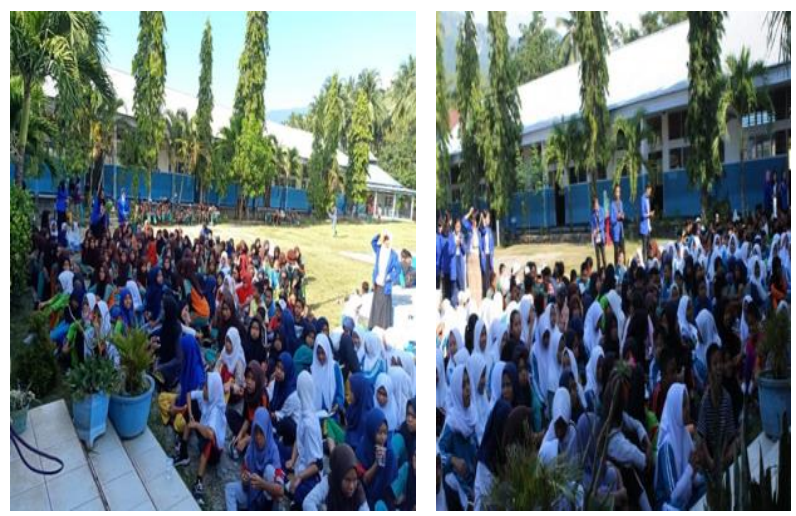

Gambar 2. Peserta Pengabdian Masyarakat

Rangkaian acara pada kegiatan penyuluhan adalah yang pertama pembukaan oleh pembawa acara (mahasiswa) kemudian sambutan Wakasek Humas dan perwakilan tim. Selanjutnya, penyampaian materi tentang pengertian, penyebab, bahaya dan cara pencegahan seks bebas. Saat penyuluhan berlangsung remaja siswa-siswi SMPN 4 terlihat antusias dalam mengikuti seluruh rangkaian kegiatan, terlihat sekali-kali mereka tersenyum tersipu malu, tertawa dan saling menunjuk dan menyebutkan nama saat materi yang disampaikan terkait dengan pembahasan pacaran. Setelah penyampaian materi, acara dilanjutkan dengan sesi tanya jawab. Dalam sesi tanya jawab, diberikan kesempatan sebanyak 5 orang siswa-siswi untuk mengajukan pertanyaan, yang berani untuk bertanya dan menyimpulkan materi mendapatkan doorprize.

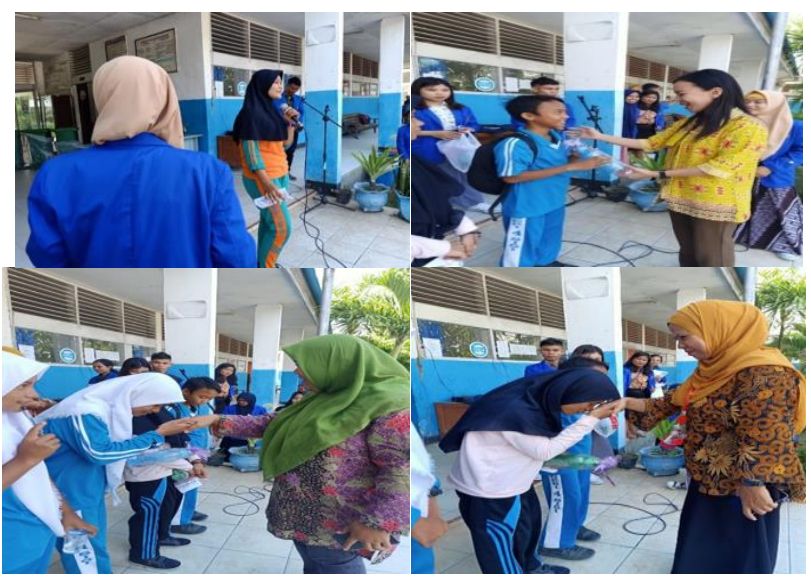

Gambar 3. Peserta Bertanya dan Menyimpulkan Materi Mendapatkan Doorpriz

Hasil observasi pada pelaksanaan penyuluhan kesehatan tentang seks bebas adalah siswa-siswi SMPN 4 Sigi telah mengetahui bahwa seks bebas dapat bermula dari memiliki teman dekat (lawan jenis) atau pacaran yang tidak sehat. Pengaruh dari pergaulan yang salah (memiliki teman yang salah), rasa penasaran akan berujung terhadap sikap ingin mencari tahu dan tindakan mencoba. Remaja akan mencoba hal-hal yang pernah didengar atau 
diperoleh dari sosial media bahwa pacaran mulai dari berduaan ditempat yang sepi, berpegangan tangan, berpelukan, melepas pakaian bagian atas, meraba bagian yang sensitif hingga berhubungan seksual adalah hal yang memberikan sensasi yang akan memberikan kepuasan dan kenikmatan, tetapi hal tersebut hanya bersifat sementara dan berujung penyesalan, dapat berdampak putus sekolah jika terjadi kehamilan bahkan penolakan dari keluarga maupun lingkungan masyarakat yang bisa berpengaruh terhadap psikologis anak remaja, serta mengalami penyakit kelamin.

\section{Lanjut daripada itu, siswa-siswi SMPN 4}

Sigi juga telah menyatakan dalam komitmen mereka untuk mencapai cita-cita yang mereka dambakan agar kelak dapat sukses dan membahagiakan orang tua. Secara kompak mereka meneriaki kata "SMPN 4 Sigi Menolak Seks Bebas", melalui berbagai hal yang dapat dilakukan dalam pencegahan seks bebas yaitu, beriman dan bertaqwa terhadap Tuhan Yang Maha Esa, mengikuti pendidikan dan penyuluhan kesehatan, menghindari perilaku yang merangsang seksual, pacaran sehat (pacaran dijadikan motivasi untuk berprestasi.

Melalui penyuluhan kesehatan tentang seks bebas, diharapkan remaja siswa-siswi SMPN 4 Sigi dapat memperoleh informasi terkait seks bebas yang berpengaruh terhadap kesehatan reproduksi dan psikologis remaja.

Kegiatan pengabdian masyarakat diakhiri dengan foto bersama guru-guru, tim, peserta dan mahasiswa.

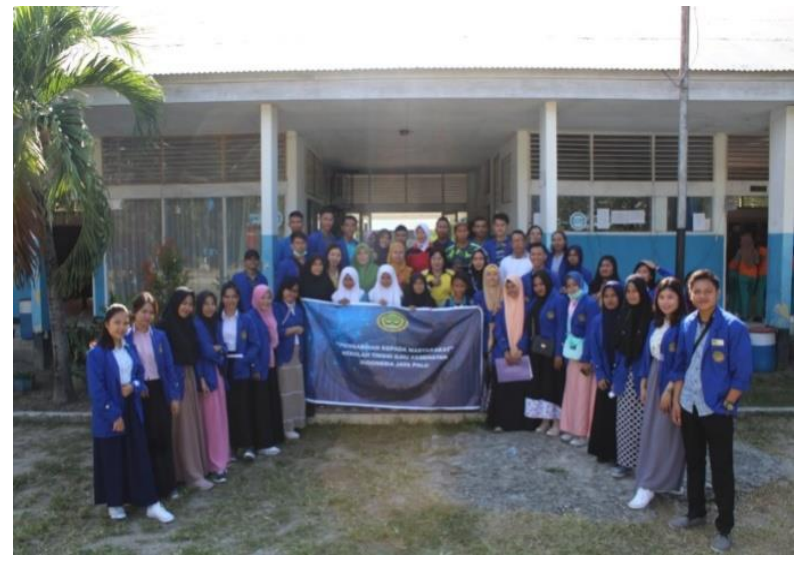

Gambar 4. Foto bersama guru, peserta, tim dan mahasiswa

\section{SIMPULAN}

Siswa-siswi SMPN 4 Sigi telah mengetahui tentang seks bebas, mulai dari pengertian, penyebab, bahaya dan cara pencegahan. Mereka juga dengan tegas mengatakan bahwa "SMPN 4 Sigi Menolak Seks Bebas". Melalui penyuluhan kesehatan tentang seks bebas, remaja siswa-siswi SMPN 4 Sigi dapat memperoleh informasi terkait seks bebas yang berpengaruh terhadap kesehatan reproduksi dan psikologis remaja.

Berdasarkan pelaksanaan kegiatan pengabdian kepada masyarakat disarankan untuk pihak sekolah memperogramkan kegiatan pengabdian masyarakat yang berkaitan dengan kesehatan reproduksi remaja. Kegiatan pengabdian masyarakat ini perlu adanya dukungan dari berbagai pihak (pemerintah, sekolah dan orang tua) baik secara moril, ataupun materiel untuk tercapainya keberhasilan yang lebih optimal.

\section{UCAPAN TERIMA KASIH}

Ucapan terima kasih disampaikan kepada LPPM STIK Indonesia Jaya yang telah mendukung terlaksananya pengabdian kepada masyarakat, 
demikian juga SMPN 4 Sigi yang telah bekerjasama dalam kegiatan pengabdian kepada masyarakat sehingga kegiatan dapat berjalan dengan baik, mahasiswa-mahasiswi PSIK STIK Indonesia Jaya yang telah membantu dalam pelaksanaan pengabdian masyarakat.

\section{DAFTAR PUSTAKA}

Allison, S., Bauermeister, J., SLightfoot, B., Mustanski, B., Shegog, R., \& Levine, D. (2008). The Intersection of Youth, Technology, and New Media with Sexual Health: Moving the Research Agenda Forward. NIH Public Access, 23(1), 1-7. https://doi.org/10.1038/jid.2014.371

BKKBN. (2017). Survei Demografi Dan Kesehatan: Kesehatan Reproduksi Remaja 2017. Badan Kependudukan Dan Keluarga Berencana Nasional, 1-606. file:///E:/JURNAL RENY/Jurnal pendukung/Seks Bebas/Laporan-SDKI2017-Remaja.pdf

Diana, A., Yuviska, I. A., Iqmy, L. O., \& Evayanti, Y. (2020). Penyuluhan tentang bahaya seks bebas mempengaruhi pengetahuan remaja. Kebidanan Malahayati, 6(1), 99-103. http://ejurnalmalahayati.ac.id/index.php/kebi danan/article/view/1732

Guse, K., Levine, D., Martins, S., Lira, A., Gaarde, J., Westmorland, W., \& Gilliam, M. (2012). Interventions using new digital media to improve adolescent sexual health: a systematic review. Journal of Adolescent Health.

http://www.jahonline.org/article/S1054139X\%2812\%2900135-8/abstract

Keswara, U. R., \& Wardiyah, A. (2017). Penyuluhan Tentang Mengenal Bahaya Seks Bebas Bagi Kesehatan Reprodukdi Remaja Di Smp Negeri 14 Bandarlampung. Kreativitas Pengabdian Kepada Masyarakat, 41(2), 84-93. ejurnalmalahayati.ac.id/index.php/kreativitas /article/download/35/pdf
Levine, D. (2011). Using Technology, New Media, and Mobile for Sexual and Reproductive Health. Sexuality Research and Social Policy, $8(1), \quad 18-26 . \quad$ https://doi.org/DOI: 10.1007/s13178-011-0040-7

Strasburger, V. C., \& Hogan, M. J. (2013). Children, adolescents, and the media. Pediatrics, 132(5), 958-961. https://doi.org/10.1542/peds.2013-2656

Sugiyanto. (2019). BAHAYA SEKS BEBAS PADA REMAJA.

http://staff.uny.ac.id/sites/default/files/tmp/B AHAYA SEKS BEBAS PADA REMAJA.pdf

Widdice, L. E., Cornel, J. L., \& Liang, W. (2006). Having Sex and Condom Use: Potential Risks and Benefits Reported by Young, Sexually Inexperienced Adolescents. Journal of Adolescent Health, 39(4), 588-595. https://doi.org/https://doi.org/10.1016/j.jadohe alth.2006.03.016 